\title{
3차원 무반사 수치파동수조에서 경사입사파의 조파기법 개발 On Generation Methods of Oblique Incidence Waves in Three-Dimensional Numerical Wave Tank with Non-Reflected System
}

\author{
허동수* • 이우동** \\ Dong Soo Hur* and Woo Dong Lee**
}

\begin{abstract}
요 지 : 본 연구에서는 3차원 수치파동수조에서 무반사 조파시스템을 이용한 경사입사파의 조파방법을 새롭게 제 안하고, 계산된 수면변위 및 수평유속에 대한 수치결과와 Stokes파의 3차 근사이론값과의 비교·분석을 통하여 새 로운 모델의 검증을 실시하였다. 그 결과 본 연구에서 제안한 경사입사파의 조파방법의 타당성과 유효성을 확인할 수 있었다.
\end{abstract}

핵심용어 : 경사입사파, 3차원 수치해석기법, 무반사 조파시스템, 부가감쇠영역

\begin{abstract}
In this study, generation methods of oblique incident wave are newly proposed and examined using the fully non-linear numerical model with non-reflected wave generation system(LES-WASS-3D). In order to verify, free surface elevation and horizontal velocities are compared with $3^{\text {rd }}$-order Stokes wave theory in 3-D oblique incident wave field. As a results, it is revealed that the numerical results by newly proposed technique are in good agreement with the theory.
\end{abstract}

Keywords : oblique incident wave, LES-WASS-3D, non-reflected wave generation system, added dissipation zone

\section{1. 서 론}

1990년대를 접어들면서 컴퓨터 기술의 발전과 함께 파동장에 대한 수치해석방법의 비약적인 발전이 있었다. 최근 들어 최 신 난류모델의 도입 및 3차원 수치모델의 개발 등으로 파랑 및 흐름 등에 대해서 보다 정확한 해석이 가능하게 되었다. 이와 같은 수치해석방법은 주어진 미분방정식을 풀기 때문에 일정한 크기의 격자로 구성되어진다. 게다가 계산시간의 단축과 보다 정확한 구조물을 재현하기 위하여 Uniform grid, Telescoping grid, Nested grid, Curvilinear grid 등과 같은 다양한 격자체 계가 개발되어 왔다. 하지만 격자크기보다 작은 구조물 또는 격자크기의 배수와 일치하지 않는 구조물에 있어서는 왜곡이 발생하게 된다. 이를 보안하기 위해 Kuroiwa et al.(2009)와 FLOW-3D ${ }^{\circledR}$ 에서는 Hirt and Sicilian(1985)이 제안한 FAVOR (Fractional Area/Volume Obstacle Representation)를 적용하 고, Lee and Mizutani(2009)는 IB(Immersed Boundary)법을 도입하고 있으며, 허 등(2008)은 유체저항을 이용한 불투과 /투과경사면에서의 처리방법을 개발하여 이용하고 있다.
한편 경사입사파에 관한 연구들을 살펴보면, 먼저 실험적인 연구들은 대부분 구조물을 경사로 배치하는 방법으로 연구를 수행하였다. Wang et al.(2008)은 경사 배치된 수중천퇴 주변의 파고분포, Zanuttigh and Lamberti(2006)는 경사 배치된 잠제 개구부의 흐름특성에 관하여 논의하였다. 이론적 해석방법의 연구로서는 Liu et al.(2007)이 경사입사파에 의한 유공방파제 전 면에서 반사율을 산정하였고, Wang et al.(2007)는 잠제에서 경사입사파에 의한 투과율을 산정하였다. 게다가 Jamois et al.(2006)은 Boussinesq 방정식을 적용한 수치모델을 이용하여 경사입사파에 의한 직립벽에서의 처오름 높이에 관하여 논의 하였다. 또한 Lee and Yoon(2007)은 새로운 내부조파기법을 mild-slope 방정식에 적용하여 다양한 형태의 조파가 가능한 새로운 수치해석기법을 제안하였다.

이러한 노력에도 불구하고 경사입사파에 대한 수치해석에 있어서 현재 내부조파 등과 같은 무반사 조파시스템을 겸비한 3 차원 N-S solver를 이용하는 첨단 수치모델의 경우를 살펴 보면, 파를 경사입사 시키는 것이 아니라 수리모형실험과 유 사하게 구조물을 경사 배치하는 경우가 거의 대부분이다. 이

*경상대학교 해양토목공학과 (Corresponding author: Dongsoo Hur, Institute of marine industry, Department of Civil and Environment Engineering, Gyeongsang National University, Tongyeong 650-160, Korea, dshur@gnu.ac.kr)

**나고야대학 공학연구과 사회기반전공 (Department of Civil Engineering, Nagoya University, Nagoya 464-8603, Japan, lwd@civil.nagoya-u.ac.jp) 
렇게 할 경우 구조물의 경사배치에 따른 구조물의 왜곡현상이 더욱 심화되게 된다. 하물며 경사입사파를 조파할 경우에 있 어서도 경계부분에서 수위 및 파고가 상승하여 장시간 조파를 할 경우 파동장에 큰 영향을 미칠 수 있다.

따라서 본 연구에서는 3 차원 경사입사파동장을 구성하기 위 하여 무반사 조파가 가능한 3차원 수치해석기법(LES-WASS$3 \mathrm{D}$; 허·이, 2007)을 개량하여 새로운 경사입사파의 조파기법 을 제안한 후, 먼저 기존 모델에 의한 경사입사파의 조파결과 와 비교하여 유효성을 검토한다. 그 후, 수면변위 및 수평유 속에 대한 Stokes파의 3차 근사이론값 및 직각입사파와의 비 교·검토를 통하여 제안한 경사입사파의 조파방법의 타당성 을 확인하는 것을 목적으로 한다.

\section{2. 수치해석기법}

\subsection{LES-WASS-3D}

$$
\begin{aligned}
& \frac{\partial\left(\gamma_{x} u\right)}{\partial x}+\frac{\partial\left(\gamma_{y} v\right)}{\partial y}+\frac{\partial\left(\gamma_{z} w\right)}{\partial z}=q_{x}^{*}+q_{y}^{*} \\
& \gamma_{v} \frac{\partial u}{\partial t}+v \frac{\partial\left(\gamma_{x} u\right)}{\partial x}+u \frac{\partial\left(\gamma_{y} u\right)}{\partial y}+w \frac{\partial\left(\gamma_{z} u\right)}{\partial z} \\
& =-\gamma_{v} \frac{1}{\partial \partial}+\left[\frac{\partial}{\partial x}\left\{\gamma_{x} v_{t}\left(2 \frac{\partial u}{\partial x}\right)\right\}+\frac{\partial}{\partial y}\left\{\gamma_{y} v_{t}\left(\frac{\partial u}{\partial y}+\frac{\partial v}{\partial x}\right)\right\}\right. \\
& +\frac{\partial}{\partial z}\left\{\gamma_{z} v_{t}\left(\frac{\partial u}{\partial z}+\frac{\partial w}{\partial x}\right)\right\}-\frac{2 v}{3} \frac{\partial q_{y}^{*}}{\partial x}-M_{x}-D_{x}-E_{x} \\
& \gamma_{v} \frac{\partial v}{\partial t}+u \frac{\partial\left(\gamma_{x} v\right)}{\partial x}+v \frac{\partial\left(\gamma_{y} v\right)}{\partial y}+w \frac{\partial\left(\gamma_{z} v\right)}{\partial z} \\
& =-\gamma_{v} \frac{1 \partial p}{\partial y}+\left[\frac{\partial}{\partial x}\left\{\gamma_{x} v_{t}\left(\frac{\partial v}{\partial x}+\frac{\partial u}{\partial y}\right)\right\}+\frac{\partial}{\partial y}\left\{\gamma_{y} v_{y}\left(2 \frac{\partial v}{\partial y}\right)\right\}\right. \\
& q_{y}^{*}=\left\{\begin{array}{l}
q_{y}(x, z, t) / \delta y_{s}: y=y_{s} \\
0
\end{array}\right. \\
& \left.+\frac{\partial}{\partial z}\left\{\gamma_{z} v_{t}\left(\frac{\partial v}{\partial z}+\frac{\partial w}{\partial y}\right)\right\}\right]-\frac{2 v}{3} \frac{\partial q_{x}^{*}}{\partial y}-M_{y}-D_{y}-E_{y} \\
& \left.\quad+\frac{\partial}{\partial z}\left\{\gamma_{z} v_{t}\left(2 \frac{\partial w}{\partial z}\right)\right\}\right]-\frac{2 v}{3} \frac{\partial\left(q_{x}^{*}+q_{y}^{*}\right)}{\partial z}-\gamma_{v} g-\beta w-M_{z}-D_{z}-E_{z} \\
& \gamma_{v} \frac{\partial w}{\partial t}+u \frac{\partial\left(\gamma_{x} w\right)}{\partial x}+v \frac{\partial\left(\gamma_{y} w\right)}{\partial y}+w \frac{\partial\left(\gamma_{z} w\right)}{\partial z} \\
& =-\gamma_{v} \frac{1 p}{\rho \partial z}+\left[\frac{\partial}{\partial x}\left\{\gamma_{x} v_{t}\left(\frac{\partial w}{\partial x}+\frac{\partial u}{\partial z}\right)\right\}+\frac{\partial}{\partial y}\left\{\gamma_{y} v_{t}\left(\frac{\partial w}{\partial y}+\frac{\partial v}{\partial z}\right)\right\}\right.
\end{aligned}
$$

본 연구에서 이용한 LES-WASS-3D는 무반사 조파를 위한 소스항이 포함된 연속방정식 (1)과 투과성 매체의 유체저항 을 도입하여 수정된 Navier-Stokes 운동방정식 (2)-(4) 및 수 면모의를 위한 $\mathrm{VOF}$ 함수의 이류방정식 (5)로 된다.

난류해석에 있어서는 Sub-Grid Scale 모델(Smagorinsky, 1963)을 이용하는 LES기법을 적용한다. 투과성 내부의 유체 저항으로서는 관성저항(Sakakiyama and Kajima, 1992), 난류저 항(Ergun, 1952; van Gent, 1995), 층류저항(van Gent, 1995; Liu and Masliyah, 1999)을 고려하는 강비선형 3차원 수치해석기 법이다.

여기서 $\mathrm{u}, v, \mathrm{w}$ 는 $\mathrm{x}, \mathrm{y}, \mathrm{z}$ 방향의 속도성분, $\gamma_{v}$ 는 체적공극율 (Volume porosity), $\gamma_{x}, \gamma_{y}, \gamma_{z}$ 는 $\mathrm{x}, \mathrm{y}, \mathrm{z}$ 방향에 대한 면적투과율 (Surface permeability)을 나타낸다. t는 시간, $\mathrm{g}$ 는 중력가속도, $\rho$ 는 유체의 밀도, $\mathrm{p}$ 는 압력, $\beta$ 는 부가감쇠영역을 제외하고는 0 으로 주어지는 파랑감쇠계수이다. 그리고 $v_{t}$ 는 유체의 동점 성계수 $(v)$ 와 난류모델에 의해 산정된 와동점성계수 $\left(v_{1}\right)$ 의 합을 의미한다. 식 (5)의 $\mathrm{F}$ 는 일정한 값을 갖는 물리량 즉, 유체의 체적율로 고려하면 식 (5)는 유체영역에서만 정의되는 식이 아닌 기체상태의 영역까지 포함하여 전 영역으로 적용이 가 능한 식으로 된다. 또한 식 (1)-(7)에 포함되어 있는 $q_{x}^{*}$ 와 $q_{y}{ }^{*}$ 는 기존의 모델에서 하나의 조파소스를 고려했던 것과는 달리 경 사입사파의 매끄러운 조파를 위하여 본 연구에서 새롭게 $\mathrm{x}$ 와 $\mathrm{y}$ 방향 각각의 조파소스로 분리하여 적용한 유량밀도로 각 방 향의 소스가 위치하지 않는 $\mathrm{x} \neq \mathrm{x}_{\mathrm{s}}, \mathrm{y} \neq \mathrm{y}_{\mathrm{s}}$ 의 위치에서는 0 으로 주어진다.

투과성구조물 내부의 유체저항으로서 $M_{x}, M_{y}, M_{z}$ 는 관성저 항, $D_{x}, D_{y}, D_{z}$ 는 난류저항, $E_{x}, E_{y}, E_{z}$ 는 층류저항를 나타낸다. 나머지 세부적인 수치해석기법에 대해서는 허·이(2007)을 참 조하기 바란다.

\section{2 경사입사파를 위한 조파소스의 경계}

무반사 조파를 위한 조파소스항이 포함된 연속방정식 (8)을 조 파소스가 설치된 격자에 대해서 체적적분하면 식 (9)와 같다. 여기서 $q_{x}$ 와 $q_{y}$ 는 $x, y$ 방향의 조파강도, $\delta x_{s}$ 와 $\delta y_{s}$ 는 조파소 스가 설치된 격자의 $\mathrm{x}, \mathrm{y}$ 방향의 격자크기를 의미한다.

식 (9)를 정리하면 식 (10)과 같이 표현할 수 있으며, 식 (10)의 양변을 $\delta x_{s}, \delta y_{s}, \delta z_{k}$ 로 나누어 정리하면 식 (11)와 같 다. 따라서 본 연구에서는 기존의 모델에서와 같이 하나의 조 파소스항만을 도입하여 $\mathrm{y}$ 방향으로 입사파의 위상차만을 고려 하여 경사입사하는 것이 아니라 식 (11)과 같이 소스항을 $q_{x}$ 와 $q_{y}$ 로 나누어 위상차뿐만 아니라 파의 입사방향도 적용할 수 있는 조파소스를 고려한다.

$$
\begin{aligned}
& \frac{\partial u}{\partial x}+\frac{\partial v}{\partial y}+\frac{\partial w}{\partial z}=q_{x}(y, z, t) \delta\left(x-x_{s}\right)+q_{y}(x, z, t) \delta\left(y-y_{s}\right) \\
& \int_{x}^{x+\delta x} \int_{y}^{+\delta y} \int_{z}^{+\delta z}\left(\frac{\partial u}{\partial x}+\frac{\partial v}{\partial y}+\frac{\partial w}{\partial z}\right) d x d y d z \\
& =\int_{x}^{+}+\delta x \int_{y}^{\beta+\delta y} \int_{z}^{+\delta z}\left\{q_{x}(y, z, t) \delta\left(x-x_{s}\right)\right\} d x d y d z
\end{aligned}
$$


$+\int_{x}^{+\infty \delta x} \int_{y}^{+\delta y} \int_{z}^{+\delta}\left\{q_{y}(x, z, t) \delta\left(y-y_{s}\right)\right\} d x d y d z$

$\left(\frac{\partial u}{\partial x}+\frac{\partial v}{\partial y}+\frac{\partial w}{\partial z}\right) \delta x_{s} \delta y_{s} \delta z_{s}$

$=q_{x}(y, z, t) \delta y_{s} \delta z_{s}+q_{y}(x, z, t) \delta x_{s} \delta z_{s}$

$\frac{\partial u}{\partial x}+\frac{\partial v}{\partial y}+\frac{\partial w}{\partial z}=q_{x}(y, x, t) / \delta x_{s}+q_{y}(x, z, t) / \delta y_{s}$

\section{3 경사입사파를 위한 개경계조건}

저자들의 이전 연구에서와 같이 3차원 수치파동수조에서 지 금까지 $q_{x}$ 의 소스항만을 이용할 경우 $\mathrm{y}$ 방향의 측면경계에 있어 서 non-slip 또는 slip 조건을 사용하였다. 하지만 경사입사파를 장시간 조파할 경우에는 수위 및 파고가 상승하여 전체적인 파동장에 영향을 미치게 된다. 그러므로 본 연구에서는 $\mathrm{x}$ 방향 뿐만 아니라 $\mathrm{y}$ 방향의 양쪽 측면경계에도 Fig. 1과 같이 개경 계조건(Open boundary)과 부가감쇠영역(Added dissipation zone)을 설치한다.

개경계조건은 Sommerfeld 방사조건을 이용하며 경사입사 파일 경우 $\mathrm{x}, \mathrm{y}$ 측면에 유입되는 파속 $(\mathrm{C})$ 이 각각 다름으로 $\mathrm{x}$ 방 향의 측면에는 식 (12), $\mathrm{y}$ 방향의 측면에는 식 (13)을 적용한 다. 여기서 $\Phi$ 는 유속과 같은 물리량을 말한다.

또한 Fig. 1과 같이 파를 흡수하는 Hinatsu(1992)의 개경 계처리 방법을 적용하여 $\mathrm{x}, \mathrm{y}$ 방향의 계산영역이 끝나는 양쪽 부분에 부가감쇠영역을 접속하고 격자크기를 변화시키면서 파 랑감쇠계수 $(\beta)$ 를 산정하여 연직방향유속 $(\mathrm{w})$ 을 서서히 감쇠시 켜 파를 흡수한다.

$$
\begin{aligned}
& \frac{\partial \phi}{\partial t} \pm C \sin \theta \frac{\partial \phi}{\partial x}=0 \\
& \frac{\partial \phi}{\partial t} \pm C \cos \theta \frac{\partial \phi}{\partial y}=0
\end{aligned}
$$

\section{4 경사입사파의 조파방법}
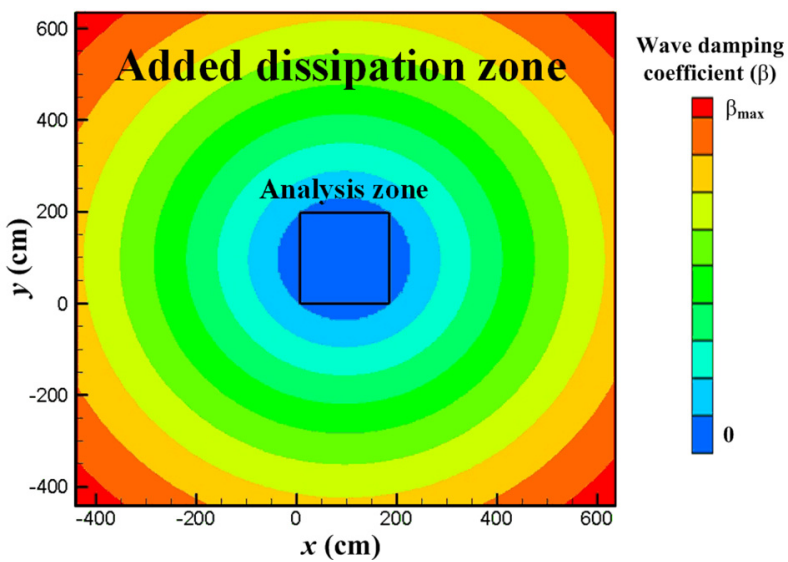

Fig. 1. Schematic of added dissipation zone in 3-D numerical wave basin.
경사입사파의 조파는 Fig. 2에 나타낸 것과 같이 조파소스 라인에서 각각의 격자에 위상차를 주어 점진적으로 조파한다. 각 격자간의 위상차는 Takayama (1982)가 경사조파를 위하여 Serpent-type의 조파시스템에 적용한 식 (14)을 이용하여 산 정한다. 여기서 $\varepsilon$ 은 격자간의 위상차, $\mathrm{L}_{\mathrm{i}}$ 는 경사입사파의 파장 $\left(\mathrm{L}_{\mathrm{i}}=\mathrm{L}_{\mathrm{y}} / \sin \theta\right), \delta \mathrm{y}_{\mathrm{s}}$ 는 조파소스가 설치된 $\mathrm{y}$ 방향의 격자크기, $\mathrm{k}$ 는 파수를 의미한다.

$$
\varepsilon=-\frac{2 \pi}{L_{y}} \delta y_{s} \cos \theta=k \delta y_{s} \cos \theta
$$

안정적인 조파를 위해 Brorsen and Larsen(1987)이 제안한 조파소스 강도식 (15)와 (16)을 적용한다. 여기서 $q_{x}, q_{y}$ 는 $\mathrm{x}$, $\mathrm{y}$ 방향의 조파소스의 강도로서 Stokes파의 3차 근사이론에 의한 수평유속 $V_{x}, V_{y}$ 를 적용, $t$ 는 조파를 시작한 시각으로부터의 경과시간, $T_{i}$ 는 경사입사파의 주기를 의미한다. 갑작스러운 조 파로 계산이 불안정해지는 것을 방지하기위해 $t / T_{i}=3$ 이 될 때 까지는 서서히 조파소스의 강도를 증가한다. 이와 함께 무반사 조파를 위해 Ohyama and Nadaoka(1991)의 $\left(\eta_{0}+\mathrm{h}\right) /\left(\eta_{\mathrm{s}}+\mathrm{h}\right)$ 를 식 (15)와 (16)에 도입한다.

$$
\begin{aligned}
& q_{x}= \begin{cases}\left\{1-\exp \left(2 t / T_{i}\right)\right\} 2 V_{x}\left(\eta_{0}+h\right) /\left(\eta_{s}+h\right) & : t / T_{i} \leq 3 \\
2 V_{x}\left(\eta_{0}+h\right) /\left(\eta_{s}+h\right) & : t / T_{i}>3\end{cases} \\
& q_{y}= \begin{cases}\left\{1-\exp \left(2 t / T_{i}\right)\right\} 2 V_{y}\left(\eta_{0}+h\right) /\left(\eta_{s}+h\right): t / T_{i} \leq 3 \\
2 V_{y}\left(\eta_{0}+h\right) /\left(\eta_{s}+h\right) & : t / T_{i}<3\end{cases}
\end{aligned}
$$

\section{3. 경사입사파의 조파방법에 관한 검증}

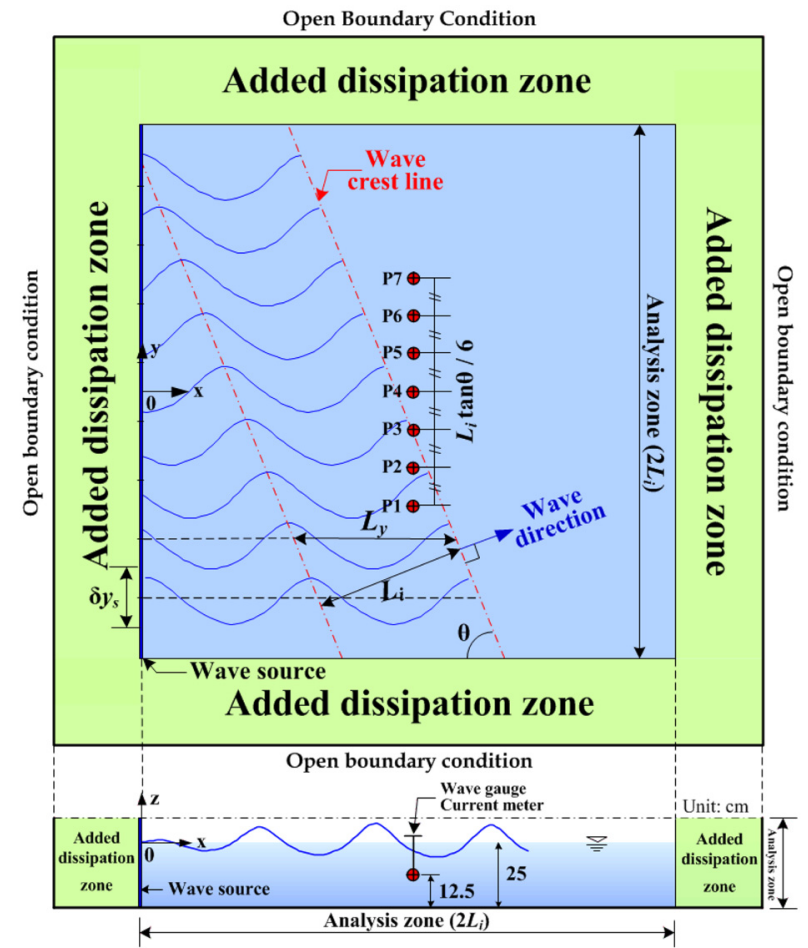

Fig. 2. Definition sketch of generation of oblique incident waves in 3-D numerical wave basin. 


\section{1 경사입사파의 조파를 위한 수치수조의 검증}

본 연구에서 적용한 무반사 경계조건의 유효성을 확인하기 위하여 Fig. 2와 같은 3 차원 수치파동수조를 이용하였으며, 계 산영역 한가운데에 조파소스를 설치하여 조파한 후, $\mathrm{x}, \mathrm{y}$ 측 면에 부가된 무반사 경계조건을 검토하였다.

Fig. 3은 정상상태 이후의 공간파형을 시간별로 나타낸 것으로 Fig. 3 에 나타내고 있는 것과 같이 부가감쇠영역에서의 파랑 감쇠와 더불어 개경계에서의 방사로 인하여 해석영역의 파동 장에 전혀 영향을 미치지 않는 것을 알 수 있다. 이에 본 연구 에서 제안하는 무반사 조파시스템에 대한 3차원 수치파동수 조의 타당성 및 유효성이 검증되었다고 판단된다.

Fig. 4는 이전의 모델과 본 연구에서 새롭게 제안한 모델의 비교를 나타내고 있는 것으로 입사각이 $\theta=60^{\circ}$ 의 경사입사 파일 경우 수면변위의 공간파형을 평면적으로 나타낸 것이다. 또한, (a)는 조파소스에서 위상차만을 고려하고 있는 이전의 모델에 의한 결과이고 (b)는 위상차뿐만 아니라 파의 방향도 함께 고려하고 있는 새로운 모델에 의한 결과를 나타내고 있 다. 그림으로부터 (a)와 같이 위상차만을 고려하여 경사입사 파를 조파할 경우에 파봉선이 매끄럽지 않고 왕관형태로 나 타나기 때문에 정확한 파동장이 형성되지 않지만(Takayama, 1982), 본 연구에서 새롭게 제안한 모델의 수치결과인 (b)와 같이 경사입사파의 위상차 및 방향성을 고려하면 굴곡이 없는 매끈한 파형을 얻을 수 있는 것을 확인할 수 있다.

\section{2 경사입사파의 수면형 검증}

Fig. 5는 Stokes파의 3차 근사이론에 의한 수면형 $(\bigcirc)$ 과 수 치파동수조의 정중앙인 P4지점(Fig. 2 참조)에서 파의 입사 각에 따라 측정한 수면형을 나타낸 것이며, - - --, -- , — 는 각각 $\theta=90,80,70,60^{\circ}$ 의 경우에 대응하고 있다. 여 기서 계산에 의한 파형의 위상은 $\theta=90^{\circ}(-)$ 를 기준으로 하 였다.

그림으로부터 입사각에 따른 각각의 시간파형이 Stokes 3 차파의 이론값을 잘 재현하고 있는 것을 확인할 수 있으며,

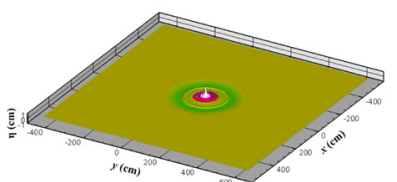

(a)

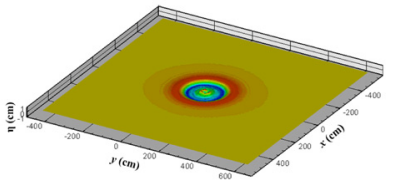

(c)

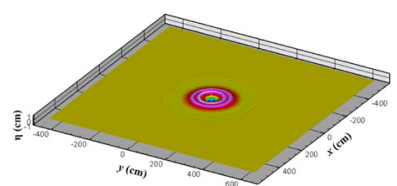

(b)

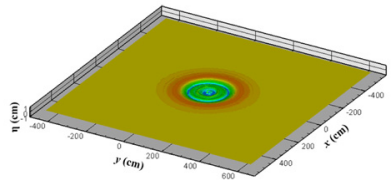

(d)
Fig. 3. Spatial distribution of free surface elevation according to time evolution. (a) $t / T_{i}=1 / 4$, (b) $t / T_{i}=2 / 4$, (c) $t / T_{i}=3 / 4$, (a) $t / T_{i}=4 / 4$.

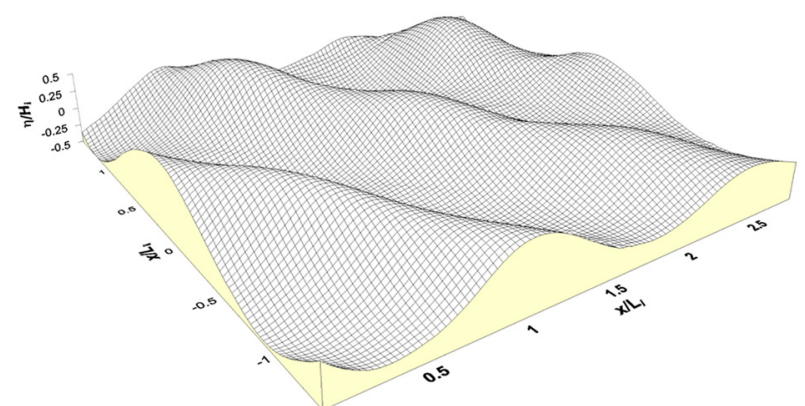

(a) Previous generation method of oblique incidence waves with only phase difference

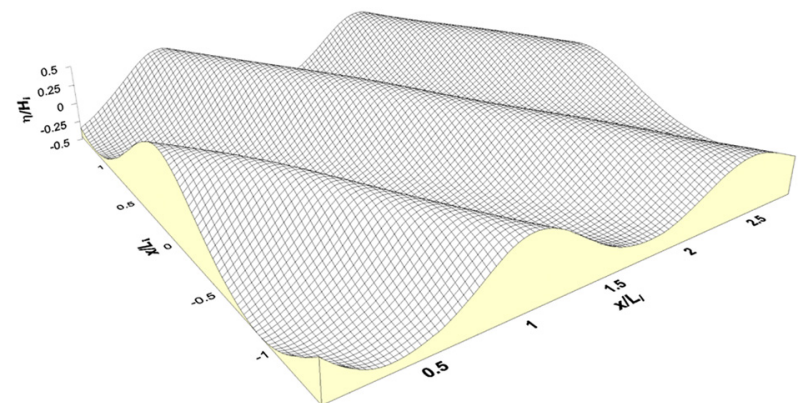

(b) New generation method of oblique incidence waves with both

Fig. 4. Comparison between plane free surface profiles obtained from previous and new model with non-reflected wave generation system.

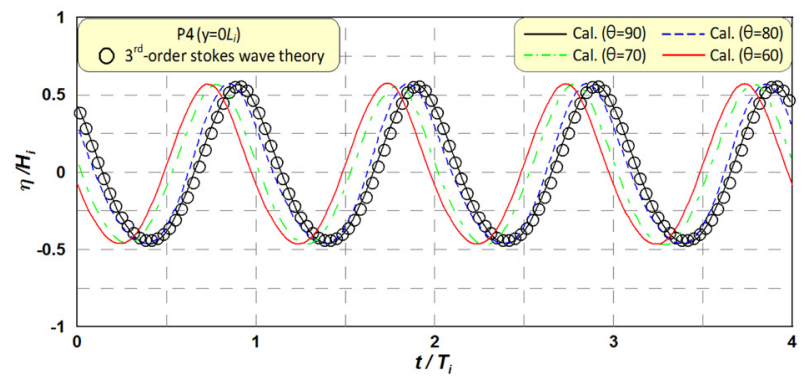

Fig. 5. Comparison between free surface elevations obtained from Stokes' $3{ }^{\text {rd }}$ wave theory and newly proposed numerical model at $\mathrm{P} 4$ according to incident wave angle.

시간파형의 위상이 위상각 $\theta=90^{\circ}$ 로부터 $\theta=60^{\circ}$ 까지 순서대 로 진행하고 있은 것을 확인할 수 있다.

Fig. 6은 Stokes파의 3차 근사이론에 의한 수면형 $(\mathrm{O})$ 과 입

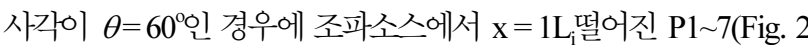
참조, $\mathrm{y}=\mathrm{L}_{\mathrm{i}} \tan \theta$ )에서의 수면형을 각각 측정한 것으로 - 는 P1 7의 시간파형을 나타낸다. 여기서 파형의 위상은 P1을 기 준으로 하였다.

Fig. 6에서 입사각이 $\theta=60^{\circ}$ 의 경사입사파일 경우에서 $\mathrm{y}$ 방 향의 거리에 따라 측정된 시간파형은 거리에 따른 위상차를 잘 재현하고 있을 뿐만 아니라, 이론값과의 비교를 통해 공간적인 파형도 잘 재현하고 있는 것을 알 수 있다.

\section{3 경사입사파의 유속 검증}




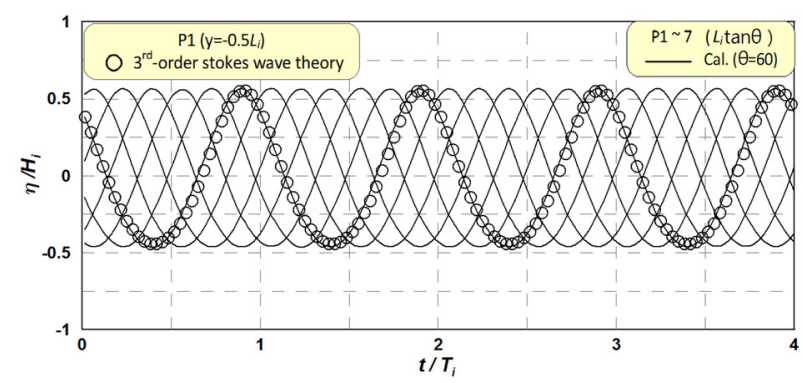

Fig. 6. Comparison between free surface elevations obtained from Stokes' $3^{\text {rd }}$ wave theory and present model for each points of y-direction at $\theta=60^{\circ}$.

Fig. 7은 Stokes파의 3차 근사이론에 의한 수평유속의 이 론값 $(\mathrm{u}: \bigcirc, \mathrm{v}: \diamond)$ 및 수치파동수조의 정중앙(P4지점)에서 측 정된 수평유속의 계산치 $(\mathrm{u}:-, \mathrm{v}:--)$ 를 나타내고 있으며, (a), (b), (c), (d)는 파의 입사각이 각각 $\theta=90,80,70,60^{\circ}$ 일 경우이다. 여기서 원활한 비교를 위하여 위상은 이론값과 일 치시켰다.

Fig. 7로부터 알 수 있는 바와 같이, 진행방향이 $\mathrm{x}$ 축과 동

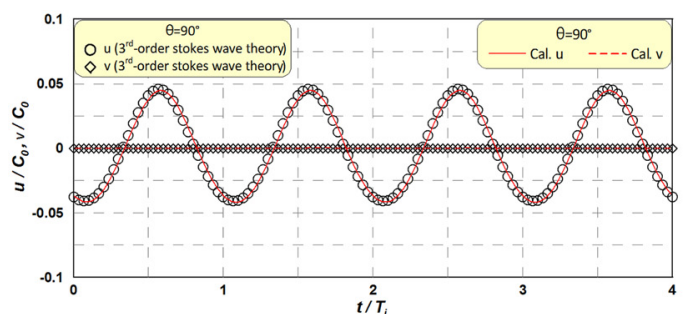

(a)

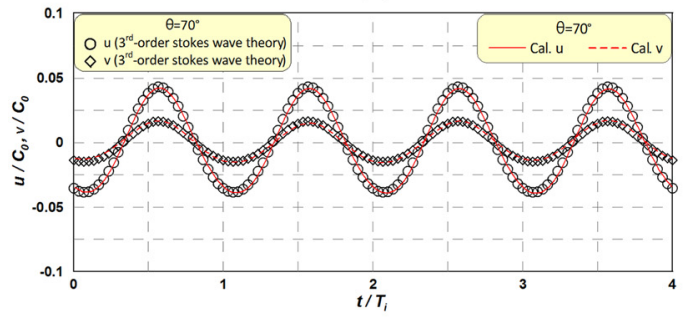

(c)
일한 입사각 $\theta=90^{\circ}$ 의 경우로부터 입사각 $\theta=60^{\circ}$ 의 경우로 갈수록 $\mathrm{x}$ 방향의 수평유속은 감소하고 $\mathrm{y}$ 방향 유속은 증가하는 이론값의 경향을 본 연구의 계산결과가 높은 정도로 재현하 고 있는 것을 확인할 수 있다. 또한, 지면 관계상 여기에 나 타내고 있지는 않지만, 파동장의 모든 위치에서 이론값에 대 한 계산치의 재현성을 확인하였다.

Fig. 8은 파의 입사각이 $\theta=60^{\circ}$ 경우에 Stokes파의 3차 근 사에 의한 수평유속의 이론값(u : $\bigcirc, \mathrm{v}: \diamond)$ 과 조파소스에서

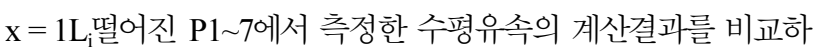
고 있으며, (a)와 (b)는 각각 $\mathrm{x}$ 방향의 유속 $\mathrm{u}$ 와 $\mathrm{y}$ 방향의 유속 $\mathrm{v}$ 를 각각 나타낸다. 또한 유속의 위상은 P1을 기준으로 하였다.

그림으로부터 본 연구에서의 계산결과는 $\mathrm{y}$ 방향의 거리에 따른 수평유속의 위상차를 잘 재현하고 있을 뿐만 아니라 Stokes 3차 파의 이론값과도 매우 잘 일치하는 것을 확인할 수 있다.

이상과 같이 본 연구에서 새롭게 제안하는 경사입사파의 조 파기법에 의해 계산된 파의 수면변위 및 수평유속이 시· 공 간적으로 Stokes 3차 파의 이론값을 높은 정도로 재현함으로서 그 적용타당성 및 유효성이 확인된 것으로 판단된다.

\section{4. 결 과}

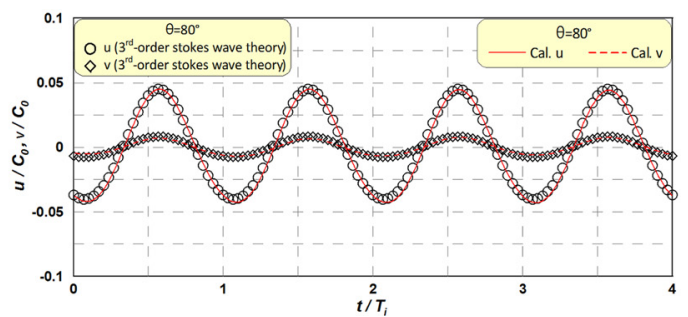

(b)

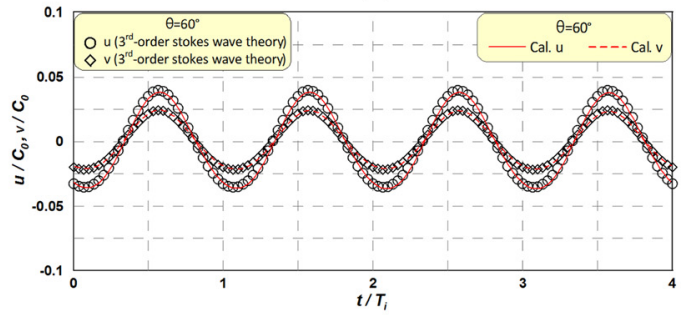

(d)

Fig. 7. Comparison between horizontal velocities obtained from Stokes' $3^{\text {rd }}$ wave theory and newly proposed numerical model according to incident wave angle. (a) $\theta-90^{\circ}$, (b) $\theta-80^{\circ}$, (c) $\theta-70^{\circ}$, (d) $\theta-60^{\circ}$

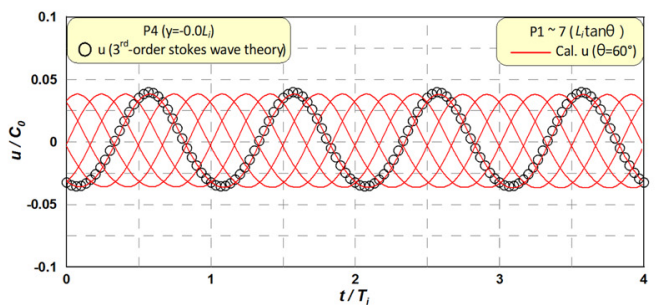

(a)

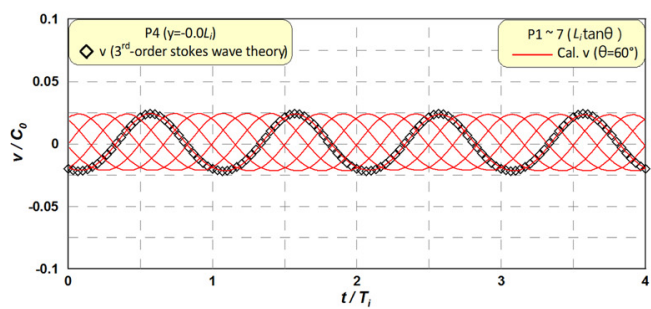

(b)

Fig. 8. Comparison between horizontal velocities obtained from Stokes' $3^{\text {rd }}$ wave theory and present model for each points of y-direction at $\theta=60^{\circ}$. (a) Velocity of $x$-direction (u), (b) Velocity of $y$-direction (v). 
본 연구에서는 3 차원 수치파동수조에서 경사입사파의 조파 방법을 검토하기 위하여 저자들의 이전 논문에서 논의된 모델 LES-WASS-3D(허·이, 2007)를 개량하여 새로운 모델을 제 안하였다.

무반사 경사입사파를 조파하기 위하여 모든 방향에 대해서 부가감쇠영역과 파의 방사가 가능한 개경계조건을 적용하여 무반사 경사입사파의 조파가 가능한 수치파동수조를 구성하 였다. 이에 Stokes파의 3차 근사이론에 의한 시간파형 및 수 평유속 $(\mathrm{u}, \mathrm{v})$ 와 입사각에 따른 경사입사파의 시 - 공간적인 파형 및 수평유속의 비교 - 분석을 통하여 3차원 수치파동수조를 바 탕으로 본 연구에서 제안하는 3 차원 수치파동수조에서의 경 사입사파의 조파방법에 관한 타당성 및 유효성을 확인하였다.

따라서 본 연구에서 제안한 3차원 수치파동수조에서의 경 사입사파의 조파방법을 적용한다면 기존에 흔히 행해지던 구 조물을 경사배치로 인한 구조물의 왜곡현상에서 충분히 탈피 할 수 있을 것으로 판단되며, 3차원 수치파동수조에서 무반 사 조파의 궁극적인 목표라고도 할 수 있는 다방향 불규칙파의 조파 가능성(원하는 방향스펙트럼 재현)에 한발 더 다가선 것 으로 평가될 수 있을 것이다.

\section{감사의 글}

이 연구는 2010년도 경상대학교연구년제연구교수 연구지 원비에 의하여 수행되었음.

\section{참고문헌}

허동수, 이우동 (2007). 잠제 주변의 파고분포 및 흐름의 3차원 특성; PART I -해빈이 없을 경우. 대한토목학회논문집, 27(6B), 689-701.

허동수, 이우동, 배기성 (2008). 사각격자체계 수치모델에서의 경 사면 처리기법에 관하여. 대한토목학회논문집, 28(5B), 591-594.

Brorsen, M. and Larsen, J. (1987). Source generation of nonlinear gravity waves with boundary integral equation method. Coastal Eng., 11, 93-113.

Ergun, S. (1952). Fluid flow through packed columns. Chem Eng., 48(2), 89-94.

Hinatsu, M. (1992). Numerical simulation of unsteady viscous nonlinear waves using moving grid system fitted on a free surface. J. kansai Soc. Nav. Archit. Japan, 217, 1-11.

Hirt, C.W. and Sicilian, J.M. (1985). A porosity technique for the definition of obstacles in rectangular cell meshes. Flow Science,
Inc. Los Alamos, New Mexico, 450-469.

Jamois, E., Fuhrman, D.R., Bingham, H.B. and Molin, B. (2006). A numerical study of nonlinear wave run-up on a vertical plate. Coastal Eng., 53, 929-945.

Kuroiwa, M., Takada, T. and Matsubara, Y. (2009). Nearshore current model using FAVOR method and infulence of grid size and eddy viscosity nearshore current field. Annual of J. Civil Eng. in the Ocean, JSCE, 25, 1239-1244 (in Japanese).

Lee, C.H. and Yoon, S.B. (2007). Internal generation of waves on an arc in a rectangular grid system. Coastal Eng., 54, 357-368.

Lee, K.H and Mizutani, N. (2009). A numerical wave tank using direct-forcing immersed boundary method and its application to wave force on a horizontal cylinder. JSCE, 51, 27-48.

Liu, Y. Lia, Y.C. and Teng, B. (2007). The reflection of oblique waves by an infinite number of partially perforated caissons. Ocean Eng., 34, 1965-1976.

Liu, S. and Masliyah, J.H. (1999). Non-linear flows in porous media. J. Non-Newtonian Fluid Mech., 86(1), 229-252.

Ohyama, T. and Nadaoka, K. (1991). Development of a numerical wave tank for analysis of non-linear and irregular wave field. Fluid Dyn. Res., 8, 231-251.

Sakakiyama, T. and Kajima, R. (1992). Numerical simulation of nonlinear wave interacting with permeable breakwater. Proc. of 22nd Intl. Conf. on Coastal Eng., ASCE, 1517-1530.

Smagorinsky, J. (1963). General circulation experiments with the primitive equation. Mon. Weath. Rev. 91(3), 99-164.

Takayama, T. (1982). Theoretical properties oblique waves generated by serpent-type wave makers. Rep. the Port and Harbor Research Institute, 21(2), 3-48.

van Gent, M.R.A. (1995). Wave interaction with permeable coastal structures. Ph.D. Thesis, Delft University The Netherlands.

Wang, B., Otta, A.K. and Chadwick, A.J. (2007). Transmission of obliquely incident waves at low-crested breakwaters_Theoretical interpretations of experimental observations. Coastal Eng., 54, 333-344.

Wang, S.K., Hsu, T.W., Weng, W.K. and Ou, S.H. (2008). A three-point method for estimating wave reflection of obliquely incident waves over a sloping bottom. Coastal Eng., 55, 125-138.

Zanuttigh, B. and Lamberti, A. (2006). Experimental analysis and numerical simulations of waves and current flows around low-crested rubble-mound structures. Journal of Waterway, Port, Coastal, and Ocean Eng., ASCE, 132(1), 10-27.

원고접수일: 2011년 4월 29일

수정본채택: 2011년 8월 23일(1차)

2011년 10월 24일(2차)

게재확정일: 2011년 11월 1일 